\title{
Wet-nursing Practice in the Malay Society According to Islamic Perspective: A Cross-Sectional Study
}

Latifah Abdul Majid, Nurhidayah Muhammad Hashim, Salasiah Hanim Hamjah, Zuliza Mohd Kusrin, Rafeah Saidon, Norsyamlina Che Abdul Rahim, Norainan Bahari

To Link this Article: http://dx.doi.org/10.6007/IJARBSS/v12-i1/11640

DOI:10.6007/IJARBSS/v12-i1/11640

Received: 06 November 2021, Revised: 10 December 2021, Accepted: 22 December 2021

Published Online: 07 January 2022

In-Text Citation: (Majid et al., 2022)

To Cite this Article: Majid, L. A., Hashim, N. M., Hamjah, S. H., Kusrin, Z. M., Saidon, R., Rahim, N. C. A., \& Bahari, N. (2022). Wet-nursing Practice in the Malay Society According to Islamic Perspective: A CrossSectional Study. International Journal of Academic Research in Business and Social Sciences, 12(1), 661 677.

\section{Copyright: (c) 2022 The Author(s)}

Published by Human Resource Management Academic Research Society (www.hrmars.com)

This article is published under the Creative Commons Attribution (CC BY 4.0) license. Anyone may reproduce, distribute, translate and create derivative works of this article (for both commercial and non0-commercial purposes), subject to full attribution to the original publication and authors. The full terms of this license may be seen at: http://creativecommons.org/licences/by/4.0/legalcode

Vol. 12, No. 1, 2022, Pg. 661 - 677

Full Terms \& Conditions of access and use can be found at http://hrmars.com/index.php/pages/detail/publication-ethics 


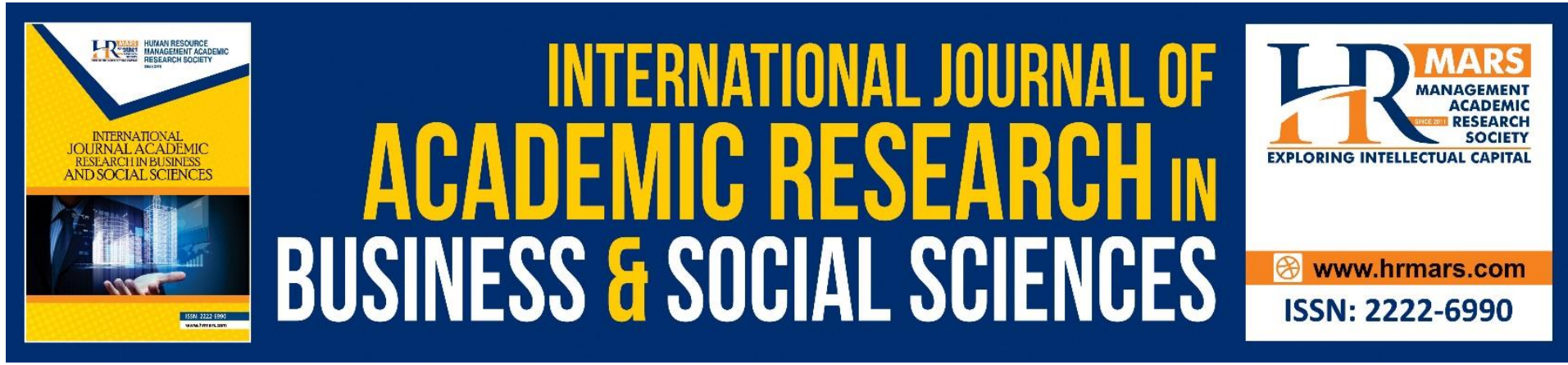

\section{Wet-nursing Practice in the Malay Society According to Islamic Perspective: A Cross- Sectional Study}

Latifah Abdul Majid', Nurhidayah Muhammad Hashim²,

Salasiah Hanim Hamjah ${ }^{3}$, Zuliza Mohd Kusrin ${ }^{4}$

${ }^{1} \mathrm{Ph}$. D. (corresponding author) Associate Prof. at Research Centre for al-Quran and alSunnah, Faculty of Islamic Studies, Universiti Kebangsaan Malaysia, 43600 BANGI, Selangor, Malaysia, ${ }^{2}$ Ph.D., Assoc. Prof. at Akademi Pengajian Islam Kontemporari, Universiti Teknologi

Mara (UiTM),Selangor, Malaysia, ${ }^{3}$ Ph.D., Assoc.Prof at Reseach Centre for Dakwah and Leadership, Faculty of Islamic Studies, Universiti Kebangsaan Malaysia, 43600 BANGI, Selangor, Malaysia, ${ }^{4}$ Ph.D. Assoc.Prof. at Centre of Syariah, Faculty of Islamic Studies, Universiti Kebangsaan Malaysia, 43600 BANGI, Selangor, Malaysia.

Email:umilm@ukm.edu.my, puan.hidayah2@gmail.com, salhanin@ukm.edu.my, zuli@ukm.edu.my

\section{Rafeah Saidon}

Ph.D. Assoc. Prof. at Akademi Pengajian Islam Kontemporari, Universiti Teknologi Mara (UiTM),Selangor, Malaysia.

Email: rafeahsaidon@hotmail.com.

\section{Norsyamlina Che Abdul Rahim}

Ph.D.,Nutritionist at Insttiute of Public Health, Ministry of Health Malaysia.

Email: syamlina_rahim@yahoo.com

\section{Norainan Bahari}

Ph.D. Lecturer at International Islamic College Selangor (KUIS), Bandar Seri Putra, 43000

Kajang, Selangor, Malaysia.

Email: norainan@kuis.edu.my

\section{Abstract}

The practice of wet nursing or breastfeeding of another woman's child(ren) in Malaysia, especially among Muslim mothers is on the rise. This is due to the emergence of public awareness of the benefits of breast milk to the children. However, it is claimed that some mothers do not have clear understanding on the Islamic rulings concerning wet nursing especially relating to mahram (prohibition to marry), nasab (lineage) and inheritance. Hence, the purpose of this article is to examine the level of understanding among Muslim mothers who have practiced breastfeeding on the legal implications of wet nursing and the factors 
influencing the practice. This was a cross-sectional descriptive study that was carried out between January and December 2019. This study was conducted on 100 Muslim mothers who had breastfed other's child(ren) in Selangor. Data were obtained using a validated questionnaire (Cronbach alpha $=0.8$ ) and processed using the SPSS software. Results shows that majority of the respondents understand the basic Islamic rulings on wet nursing especially on the prohibited person to marry, conditions and method of feeding. However, the respondents need to understand further on the rulings relating to nasab (lineage), guardianship and inheritance involving the milk child. It is also demostrated various factors that have influenced the wet-nursing practice in society. This study has significant implications on the need to have more activities to create awareness and enhance understanding relating to wet-nursing among Muslim women in the society. Furthermore, it is recommended that formal documentation should be systematically implemented by the authorities. As such, more research studies related to wet nursing and the impact of the practice should be conducted to offer better solutions to the society.

Keywords: Wet Nursing Practice, Breasfeeding of Another Woman's Children, Islamic Ruling, Formal Documentation, Methode.

\section{Introduction}

Many studies have proven that mother's milk is highly nutritious for baby's growth. It is considered the best food for a newborn until six-month old baby as it contains complete nutrients for its requirements (Majani et al., 2021)Based on this, many mothers make efforts to give mother's milk to their babies from birth as their main food.

From the religious perspective, Islam recommends this practice and outlines some rules which grew from this practice, including matters of mahram, aurat rules between foster parents and foster children, and so on. This matter was noted when the Prophet (pbuh) remarked on the daughter of his foster brother, Sayidina Hamzah, son to the Prophet's (pbuh) first foster mother named Suwaibah. The Prophet (pbuh) said," She is not halal for me. What is forbidden in consanguinity is also forbidden by reason of milk feeding. She is my foster niece." (Al-Bukhari, No 2645)

In reference to the Malay society in Malaysia, breastfeeding is frequently practised, by mothers who nurse their biological babies as well as by wet nurses for other women's babies. The question regarding wet nurses is whether they take note of the the legal effects of doing so. A past study showed that there are two different situations. In the first situation, wet nurses keep a written record of the names of children they nursed for future reference on mahram and so on. The other situation showed that not a few wet nurses fail to keep any kind of records, relying only on memory of having nursed the child of so and so (Safir et al., 2015)

Concerning wet-nursing or breastfeeding others' babies, various legal rules need to be given attention. Hence, wet nurses should know the legal effects applicable from their action, including non-marriageability, the mahram status during journeys, nafkah rule, inheritance beneficiaries and guardianship affairs, and so on. Thus, understanding the legal effects needs to be given serious attention by all levels of society so that issues do not arise in the future. 


\section{Research Objectives}

This article aims:

- to analyse the practice of wet-nursing in the Malay society

- to determine whether it complies with the nas (legal injunction) of Quranic and Sunnah and

- to determine the wet nurses' level of understanding of the legal effects of wetnursing.

\section{Research Methodology}

This research is an inferential study using quantitative and qualitative data obtained through questionnaire and interview. These methods are considered most relevant to achieve the set objectives. Data obtained from purposive sampling was analysed and presented in the form descriptive statistics and test significance. Characteristics of the population tested were then inferred from results of statistical tests.

For the purpose of data collection, this research used document analysis approach, i.e., studying and gathering the results of past writings related to breastfeeding, law on breastfeeding and the practice of wet-nursing through breastfeeding or sale of frozen breast milk. This included books, including fiqh and tafsir books, journals, working papers, magazine articles and newspapers that discuss this matter as well as laws or rules relating to breastfeeding.

The research instrument used is the questionnaire. It was applied to 100 respondent MuslimMalay wet nurses as this was a practical sampling method to obtain the sample needed to achieve the outlined objective. The online questionnaire, consisting of three main parts, namely demography, understanding and wet nursing practised, was distributed to the email addresses of the 100 wet nurses in the State of Selangor.

Wet nurses' participation was based on the procedure of purposive sampling, whereby they were selected by certain fixed criteria as respondents. According to the categories set, wet nurses who did not satisfy all the criteria were not chosen to participate. The criteria were as follows:

- $\quad$ Resident in Selangor

- $\quad$ Aged between 18 years to 50 years

- $\quad$ Able to speak and write English language or Bahasa Malaysia

- Mothers who have been/were involved in wet nursing at the time of this research.

- $\quad$ Agree to be interviewed

Disqualifying Criteria

- Have never nursed others' babies before this.

- $\quad$ Aged more than 50 years

In support of primary data, semi-structured interviews were conducted with expert researchers in the field of breastfeeding. They were Prof Madya Dr Normadiah Daud, Dr Siti Fatimah Salleh and Dr Zilal Saari. Other experts interviewed were Datuk Dr Anhar Opir, the Deputy Mufti of Selangor, Ustazah Mariam Md Zin from Legal Section of JAIS (BUU JAIS- 
MyRadhaah), Puan Siti Mariam Ali, Food Science Officer from National Lactation Centre. The questionnaires were processed using software, Statistical Package for Social Sciences (SPSS) version 22, to determine some important results involvng the research objectives. Data from interview with experts were recorded and transcribed verbatim.

\section{Findings and Discussion \\ Respondents' Background}

Research respondents comprised of those aged between 20- 50 years. Among them, the biggest group who wet-nursed were aged between $31-40$ years (64\%). The second biggest group of respondents were aged between 21-30 tahun (30\%) and the smallest group of respondents were aged between $41-50$ years $(6 \%)$. The conclusion reached is that most younger women do not participate in wet-nursing. Perhaps this is due to factors such as too young in age or lack of experience or less interest to do so. Research also shows that respondents aged 50 and above also do not wet-nurse, most probably due to the advanced age factor.

\section{Understanding of Legal Rules on Wet-Nursing}

This research finds that the item with the highest mean value is 'A foster child is forbidden to marry its foster parent' (mean=3.67). This finding shows that $99 \%$ of respondents in this research agreed and strongly agreed that foster children cannot marry their foster parents. Only $1 \%$ of respondents strongly disagreed with this item. The item with the second highest mean value is 'A foster child cannot marry the offspring of its foster mother' (mean=3.65). 67\% respondents in this research strongly agreed with this item while $32 \%$ agreed with it. Only $1 \%$ strongly disagreed with it.

This finding shows that most respondents understand the basic legal rules relating to the prohibition of marriage between foster children and their foster parents similar to the prohibition between biological chldren and parents. This is stated by IAllah SWT in al-Quran, surah al-Nisa' verse 23;

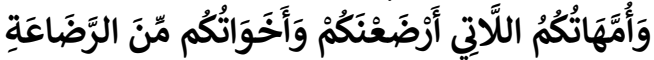

Meaning: Prohibited to you (for marriage) are: .... foster mothers who nursed you, and foster sisters through nursing...

The above Quranic verse shows that by virtue of breastfeeding or nursing, a mother becomes the foster mother of the child and her daughters become its foster sisters.

Additionally, there is a hadith which explains that the effect of wet-nursing is to place the foster mother in the same rank as a biological mother. Hence, a wet nurse is included in the list of foster mother and female foster relatives who are forbidden to the foster child for marriage just as the list of his biological mother and his own female relatives are forbidden to him. Saidatina Aisyah (RA) narrated that:

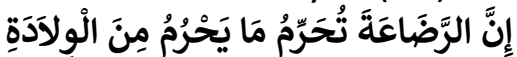

Meaning: "Wet-nursing causes the milk child (foster child) to be unmarriageable, as if the child was born (by her)." (al-Bukhari (2553) and Muslim (4144).

Likewise, another hadith from Ibn Abbas (R.A):

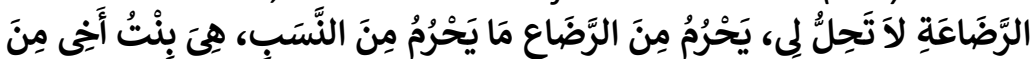

Meaning: (The Prophet (pbuh) said of the daughter of Hamzah (RA)). She is not halal for me. What is forbidden in consanguinity is also forbidden by nursing. She is my foster niece." (al-Bukhari (2502) and Muslim (1447). 
Further, research shows that the item with lowest mean value between $1.54-1.67$ is for item 'Islam only allows wet-nursing through breastfeeding' (mean=1.54). This is followed by item 'a baby given pumped breast milk using a feeding bottle does not legally become a foster child' (mean=1.57). This finding explains that $97 \%$ of respondents strongly disgreed and disagreed that Islam allows wet nursing only through breastfeeding. This shows that respondents have a high understanding that Islam allows other methods such as using a bottle, syringe, spoon, cup and tube for feeding other than direct breastfeeding. However, there are differing views on this point such as: Ibn Hazm explained that verse 23 in surah alNisa' gives the impression that babies must be fed by women directly from the breast, not using an in-between article. If it is indirect using an in-between article or mixed with other food, it does make the baby mahram to the wet nurse (Nurmadiah et al., 2012).

Findings concerning this matter may be considered as in line with the findings of expert Zilal Saari, (lecturer at UTM, Skudai) who had done a study of it in the year 2015. She, as one of the experts interviewed in this research, stated that many know the basics, but lack understanding as a whole relating to other legal rules arising from the practice of wet-nursing:

\begin{abstract}
...based on a study done in the year 2015 entitled "Garis Panduan Penyusuan Anak Angkat Dari Perspektif Figh dan Sains (Guidelines for Breastfeeding a Foster Child from the Perspective of Figh and Science) ", it is found that the level of understanding is moderate and only covers the basics of breastfeeding such as not-nullifying wuduk (ablution), permissibility to touch, embrace, hug and kiss. But they do not know other legal rules involved. It depends on their own iniative to ask the ustaz. In terms of reading and further exposure, it is lacking and difficult to get accurate information.
\end{abstract}

This shows that respondents understand the rules on wet-nursing from the point of mahram and the methods of feeding breast milk according to the Islamic perspective. However knowledge on wet-nursing needs to be enhanced because various aspects must be given attention by wet nurses so that the practice of wet-nursing complies with rules and methods of Shariah.

\title{
Factors for Wet-Nursing
}

Past studies found that the practice of wet-nursing increased in the society due to mothers' awareness of its benefits, especially the high immunity developed in baby's health from breastfeeding compared to feeding with infant formula (Al-Abdali, 2008). This matter is quite in line with mean analysis which indicates that the highest mean value (mean=3.36) is related to this point in item 'I wet-nurse to help mothers who do not have sufficient breast milk' achieved $92 \%$ agreed and $8 \%$ disagreed. Followed by item, 'I wet-nurse because I have surplus milk' (mean=3.18) which scored $84 \%$ agreed and $16 \%$ disagreed. Further, item 'I wetnurse because some mothers have health problems which prevent them from breastfeeding' (mean=3.01) showed $73 \%$ agreed and $27 \%$ disagreed with the statement.

On average, the item with the least agreement is item, 'I wet-nurse as a source of income' (mean=1.41) obtained 1\% agreed and the rest, 99\%, disagreed. Research findings show that respondents' high concern encouraged them to wet-nurse to help mothers who 
have insufficient milk rather than wet-nursing purely for extra money and so on. In reality, all respondents have their own reasons for wet-nursing.

Additionally, results of interview with experts show that one of the factors for wetnursing is to make another's child as mahram to the foster parents. This was also the factor most stated by mothers who attended National Lactation Centre. Puan Maryam Ali, counselor at National Lactation Centre stated that:

Based on our records, the majority of mothers breastfeed another's child because they wish to make another's child as mahram to themselves, their husbands and their offspring. For example, they adopt a child. They wish to adopt the child as mahram so the (would-be) adopted mother or father come to the National Lactation Centre to seek advice to carry out their wish.

In comparison to Quranic verses and the Prophet's (pbuh) hadith on the subject of wet-nursing, the above finding indicates quite a strong connection. It shows that a mother who breastfeeds another's child focuses not only on the nutrition of breast-milk but also takes into account the issue of mahram between the nursed child and the foster mother's family.

Breastfeeding makes a child a member of the foster family and non-marriageable or forbidden to marry, if the condition is satisfied, namely, the child must be aged before two years old. If its age is two years or more, the breastfeeding does not make it mahram and thus the child does not become a foster child of the woman who nursed it.

This matter is based on Allah's SWT command in al-Quran, surah al-Baqarah 2:233:

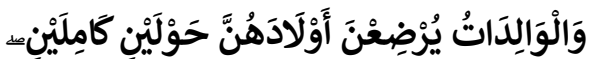

Meaning: And mothers should suckle their children for two whole years, that is, for those (parents) who desire to complete the term for suckling

Allah SWT commands again:

وَفِصَالُهُ فِي عَامَيْنِ

Meaning: ... and their weaning takes two years...

(Surah Luqman, 31:14)

Similarly, a hadith narrated by al-Daraqutni:

لاَرَضَاعَ إِلَّ مَاكانَ فِفَ الْحَوْلَيْنِ

Meaning: "Breastfeeding is within the age of two years."

Riwayat Al-Daraqutni (4/174)

In another hadith from Ummu Salamah R.A:

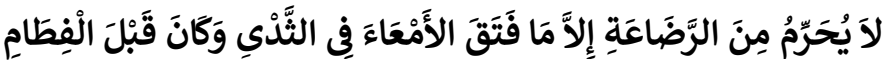

Meaning: "A wet-nursed child does not become mahram except if the milk enters its stomach in breastfeeding before the child is weaned off the breast."

Riwayat Al-Tirmidhi (1152)

This means that the child is weaned off the breast before it reaches the age of two years, as mentioned in surah Luqman above.

\section{Experience and Challenges of Breastfeeding \\ Absence of Records or Documentation}

Women who nurse babies go through various experiences and challenges. Research results find that item 'I have experienced forgetting which child I have nursed' obtained 95\% (95 persons) of respondents who chose strongly disagreed and disagreed while $5 \%$ (5 persons) chose to answer strongly agreed and agreed with the item. This shows that only a handful in 
society are not concerned with keeping information on their foster children so they do not remember their names or background.

This contravenes the Prophet's (pbuh) hadith that recommends every foster mother to know about her foster children. As narrated by Aishah (RA), the Prophet (pbuh) said:

The moment the Prophet (pbuh) entered, at the time there was a man next to me. So he asked: O Aishah, who is this person? I replied: He is my foster brother. He replied: O Aishah, remember who your foster brothers are. Because wet-nursing happens due to hunger.

Muslim (1455)

This hadith indicates how important it is for a foster mother, including her husband and family members, and the foster child to know the foster relatives who are mahram for them in order to avoid undesirable consequences in the future such as prohibited marriage between foster relatives.

This indicates the need for a method of documentation relating to wet-nursing in order to help wet nurses and their foster children know and recognise one another. Moreover, with the passage of time and changing places of residence, documentation can help to save from harm due to forgetting who are involved in the wet-nursing.

Research also finds that a handful of respondents had even been involved in marriage between their foster child and their family member with the foster father as the marriage guardian of the foster daughter. This was admitted for item 'I have experienced annulment of marriage between a foster child and a member of the foster family', which obtained $5 \%$ ( 5 persons) of respondents agreed and 95\% (95 persons) disagreed. The item 'I have experienced a foster father become marriage guardian for a foster child' showed $3 \%$ (3 persons) agreed and $97 \%$ (97 persons) disagreed.

\section{Will (Wasiat) and Gift (Hibah)}

When respondents were asked relating to will (wasiat) and gift (hibah) for a foster child, research finds the item, 'I have granted ownership of property (hibah) to a foster child' obtained 13\% (13 persons) agreed and $87 \%$ ( 87 persons) disagreed, and item 'I have bequeathed property by will (wasiat) to a foster child' obtained 93\% (93 persons) of respondents chose strongly disagreed and $7 \%$ (7 persons) strongly agreed and agreed with the item.

The above findings generally show that there are still respondents who do not understand the effects of wet-nursing. According to Zuhaili (2007) Islam has established that the effects of wet-nursing to nasab (lineage) only involves two legal rules. The first relates to prohibition of marriage of foster mother or father and their lineage to the foster child. Second is that It is permissible for a foster child to mix with (look at what is forbidden to non-mahram) the foster mother and her lineage and to live with them. This explanation excludes nasab laws on a foster child's inheritance rights, maintenance, guardianship, custody and so (Zuhaili, 2007) 
Hence, research results on the experience and challenges to wet-nursing indicate that respondents' understanding in the process of wet-nursing according to Islam is still at moderate level. Even though the negative issues arising from wet-nursing constitute a small percentage, this cannot be underestimated. This is because wet-nursing is connected to various Islamic laws such as prohibition of marriage, permissibility of proximity (khalwat), mahram status for journeys, no responsibilty for maintenance and inheritance rights, and guardianship for marriage (Alu Bassam, 2019). Therefore, a method of keeping documentation on information about foster mothers and their foster children would be a step toward solving the problem to prevent forbidden relationships between a foster child and foster mother or father and their relatives in the future.

\section{Receive Payment for Wet-Nursing}

Research findings prove that the majority of respondents ( $94 \%$ or 94 persons) have never received any payment for wet-nursing done. Only a handful of them ( $4 \%$ or 4 persons) have received a payment of $\mathrm{RM} 100$, while 2 persons received $\mathrm{RM} 1$ and $\mathrm{RM} 50$ respectively ( $2 \%$ or 2 persons).

According to the Islamic view, wet nurses are entitled to receive payment and kind treatment from the guardian of the foster child as stated by Allah SWT in al-Quran, surah Baqarah verse 23:

... And if you wish to give your children out to a (milk feeding ) nurse, it is no sin for you, provided, you pay to them what is agreed, with kindness (al-Baqarah 233)

Based on Sayyid Qutb's interpretation (1997), the act of paying compensation to a wet nurse is a guarantee that the child will get a foster mother who acts as a good adviser, caregiver and babysitter for the child. This shows that wet nurses are entitled to compensation for the efforts to nurse and take care of other people's children.

Ths situation is also in line with a legal provision in the Selangor family law to give priority to divorced women to nurse their children in the interest and welfare of the children. The legal provision is Section 82 (1) of Islamic Family Law (State of Selangor) Enactment, 2003 (Enakmen Undang-undang Keluarga Islam, Selangor 2003):

Subject to Section 82, the mother shall be of all persons the best entitled to the custody of her infant children during the connubial relationship as well as after its dissolution.

This means that if a couple is divorced when a child is an infant (below 2 years old), the court shall decide the custody of the child to the mother, and the father must pay child maintenance and compensation for nursing the child to the former wife.

Hence, any couple, whose child is still being nursed, cannot use the child for the purpose of taking revenge. For example, a man who is furious or hateful toward his former wife does not give maintenance after the iddah period of divorce; Or a man who is fuming over his wife's filing for divorce in court, reacted by running off with his child and feeding it wiith infant formula, during the period when it is still being nursed by its mother. His intention is to deny her custody of their child but the effect is to deny the child of its right to be nursed. 
Divorced wives too should not harass the ex-husband because of her hurt feelings by demanding a high price beyond his means for nursing their child. She also cannot deny him joint custody of their child or the child's right to the father's love and affection. All these indicate that Islam puts the child's interest above the interest of its parents.

\section{Frequency of Breastfeeding}

The majority of respondents (82\%) have only one foster child (five or more feedings) while $21 \%$ have six foster children (five or more feedings). However some respondents stated that they have nursed with less than five feeding times. This shows that the percentage of respondents who feed five times or more is high. Al-Imam al-Syafi'e and al-Imam Ahmad viewed that the rate of feedings (to qualify as a foster child) is five or more feedings that satiate the child. This is based on a hadith narrated by Saidatina Aisyah R.A:

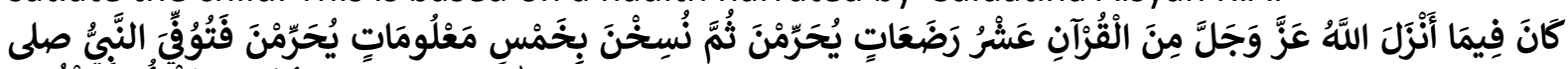

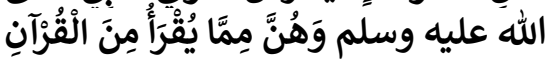

Meaning: " It was revealed by Allah SWT in al-Quran ten sucklings ( make marriage unlawful), then it was abrogated and (substituted by) five sucklings. Then the Prophet (pbuh) died, it was in the Holy Quran and recited at that time.

Sahih Muslim, No. 1452

One feeding is when the baby is fed and then it lets go the milk on its own without any interference because it is satiated.

\section{Conclusion}

In Islam, wet-nursing or breastfeeding another woman's child is not disputed. This matter is stated in al-Qur'an and as-Sunnah. However, from the above discussion shows that among the Malays, there are still those who do not understand the legal effect of wet-nursing, such as marriage prohibition, no responsibility for maintainence and to bequeath inheritance, and no guardianship for marriage. The findings suggest that the practice of wet-nursing in the society still lacks full compliance with Islamic law because the level of understanding concerning the effects of breastfeeding others' children based on Islamic law is still moderate. This was proven by the indifference of some of the respondents to information on wetnursing leading to marriage between a foster child and a family member of the foster mother's, as well as a foster mother's husband assuming guardianship of the foster child. Therefore, this study suggests that the authorities take drastic measures to aggressively implement knowledge empowerment programmes, even to the extent of promoting legislative amendments, so that the correct practice of wet-nursing is emphasised in society. Furthermore, it is recommended that formal documentation should be systematically implemented by the authorities.

Wet-nursing in the Malay society is being increasingly accepted due to various encouraging factors such as concern of mothers who are unable to nurse their own child, mothers who have surplus milk and as a measure to create nasab between a foster child and the foster mother and her family required by Islamic law. Most women who wet-nurse understand the law relating to foster children. However, the level of understanding of wet nurses is still at moderate level because they know only the basic law. In fact, laws relating to wet-nursing cover various aspects that need attention, such as prohibition of marriage, permissibility of proximity (khalwat), mahram status during journeys, no responsibility for maintenance, inheritance and marriage guardianship. Thus, efforts need to emphasize on 
increasing awareness of the legal effects of wet-nursing in the Malay society, so that the practice of wet-nursing complies with nas (legal injunctions) in Shariah established by Islam.

\section{References}

Abdullah, A. S., \& Razali, N. M. (2017). Publication . Retrieved from Bank Negara Malaysia: https://www.bnm.gov.my/files/publication/qb/2017/Q2/p5_ba1.pdf

Albright, T. D. (2017). Why eyewitnesses fail. Proceedings of the National Academy of Sciences of the United States of America, 114(30), 7758-7764. doi:10.1073/pnas.1706891114

Al-Bukhari, A. (2000). Sahih al-Bukhari dalam Mawsu'a al-Hadith al-Syarif Kutub al-Sitta. Riyadh: Dar al-Salam.

Al-Daraqutni, \& Al-Daraqutni, A. (2020). Sunan al-Daraqutni: Himpunan Hadis-Hadis Imam alDaraqutni. Johor Bharu: Jahabersa.

Alić, J. (2017). The 3 Levels of English Pronunciation Mistakes. Retrieved from Speechling: https://speechling.com/blog/the-3-levels-of-english-pronunciation-mistakes/

Al-Khresheh, M. H. (2016). A Review Study of Error Analysis Theory. International Journal of Humanities and Social Science Research Vol 2, 49-59.

Al-Abdali, N. Al-S. F.-S. (2008). Sains dari Perspektif Kitab Samawi. Kuala Lumpur: Institut Terjemahan \& Buku Malaysia.

Al-Abdali, Al-S. N. F.-S. (2008). Sains dari Perspektif Kitab Samawi. Kuala Lumpur: Institut Terjemahan \& Buku Malaysia.

Al-Tirmidhi, A. (2000). Jami' al-Tirmidhi dalam Mawsu'ah al-Hadith al-Syarif Kutub al-Sittah. n.p.

Alu Bassam, A. (2019). Syarah Hadits Pilihan Bukhari-Muslim. Jakarta: Darul Falah.

Aman, R., Kechot, A. A. H. S. (2012). Production And Perception Of English Word Final Stops By Malay Speakers. GEMA Online ${ }^{T M}$ Journal of Language Studies Volume 12(4), 11091124.

Ambalegin, \& Suryani, M. S. (2018). Mother Tongue Affecting the English Vowel Pronounciation of Batak Toba Adults. KnE Social Sciences, 3(4), 78-86.

Anderson, C. (2018). Essentials of Linguistics Open textbook library. Canada: McMaster University. Retrieved from Pressbooks.

Arkoudis, S., Hawthorne, L., Baik, C., Hawthorne, G., O'Loughlin, K., Leach, D., \& Bexley, E. (2009). The impact of English language proficiency and workplace readiness on employment outcomes and performance of tertiary international students. Melbourne: The University of Melbourne.

Aspiring Minds. (2014). National Spoken English Skills Report. Retrieved from Aspiring Minds: http://www.aspiringminds.com/sites/default/files/National\%20Spoken\%20English\%2 0Skills\%20\%28NSES\%29\%20Report.pdf

Aziz, M., Rahayu, T., Permatasari , I., Maftuh, M. F., \& Ridho, M. (2021). An Error Analysis of English Monophthongs Pronunciation in Speaking. Proceedings of the First International Conference on Economics, Business and Social Humanities, ICONEBS 2020. doi:10.4108/eai.4-11-2020.2304542

Azmi, M. N., Ching, L. T., Jamaludin, N. B., Ramli, M. N., Razali, M. H., Amram, M. A., \& Jayakumar, K. A. (2016). The comparison and contrasts between English and Malay languages. Journal of English Education Vol. 4, Issue 2, 209-218.

Bank Negara Malaysia. (2009). Bank Negara Annual Report 2009. Kuala Lumpur : Bank Negara Malaysia . 
Bank Negara Malaysia. (2014). Bank Negara Malaysia Annual Report 2014. Kuala Lumpur: Bank Negara Malaysia.

Bank Negara Malaysia. (2017). Bank Negara Annual Report 2017. Kuala Lumpur: Bank Negara Malaysia.

Beaudry, J. L., Lindsay, R. C., Leach, A.-M., Mansour, J. K., Bertrand, M. I., \& Kalmet, N. (2015). The effect of evidence type, identification accuracy, line-up presentation, and line-up administration on observers' perceptions of eyewitnesses. Legal and Criminology Psychology, 20(2), 343-364. doi:10.1111/lcrp.12030

Beaudry, J., Lindsay, R., Leach, A., Mansour, J., Bertrand, M., \& Kalmet, M. (2015). The effect of evidence type, identification accuracy, line-up presentation, and line-up administration on observers' perceptions of eyewitnesses. Legal and Criminological Psychology, 20(2), 343-364.

Begakis, C. (2017). Eyewitness Misidentification: A Comparative Analysis Between the United States and England. Santa Clara Journal of International Law, 15(2), 175-195. Retrieved from https://digitalcommons.law.scu.edu/cgi/viewcontent.cgi?article=1222\&context=scujil

Berman, M. K. (2015). Eyewitness Identification Jury Instructions: Do They Enhance Evidence Evaluation? New York: CUNY Academic Works. Retrieved from https://academicworks.cuny.edu/cgi/viewcontent.cgi?referer=https://www.google.co $\mathrm{m} /$ \&httpsredir=1\&article $=1874 \&$ context=gc_etds

Bhattarai, S., \& Neely, C. (2016). A Survey of the Empirical Literature on U.S. Unconventional Monetary Policy. Federal Reserve Bank of St. Louis Working Paper Series No.2016-21, 149.

Board of Governors of the Federal Reserve System. (2009). 96th Annual Report . Washington DC: Board of Governors of the Federal Reserve System.

Burns, A., \& Richards, J. C. (2018). The Cambridge Guide to Learning English as a Second Language. Cambridge University Press.

Carlson, C., Dias, J., Weatherford, D., \& Carlson, M. (2013). An investigation of the weapon focus effect and the confidence-accuracy relationship for eyewitness identification. Journal of Applied Research in Memory and Cognition, 6(1), 82-92.

Charman, S. D., Carol, R. N., \& Shwartz, S. L. (2018). The effect of biased lineup instructions on eyewitness identification confidence. Applied Cognitive Psychology, 32(3), 287-297.

Cowan, S., Read, J. D., \& Lindsay, D. S. (2014). Predicting and postdicting eyewitness accuracy and confidence. Jour al of Applied Research in Memory and Cognition, 3(1), 21-30.

Creswell, J. W. (2013). Qualitative Inquiry and Research Design : Choosing Among Five Approaches. e United States of America: SAGE Publications.

Dahl, M., Graner, S., Fransson, P., Bertillson, J., \& Fredricksson, P. (2018). Analysis of eyewitness testimony in a police shooting with fatal outcome-manifestations of spatial and temporal distortions. Cogent Psychology, 1487271.

David, M. E., \& Amey, M. J. (2020). The SAGE Encyclopedia of Higher Education. London: SAGE Publications Ltd.

Dawood, H. S., \& Atawneh, D. A. (2015). Assimilation of Consonants in English and Assimilation of the Definite Article in Arabic. American Research Journal of English and Literature Vol 1 (4), 9-15.

Dörnyei, Z. (2010). The L2 Motivational Self System. In Z. Dörnyei, \& E. Ushioda, Motivation, language identity and the L2 self (pp. 9-42). Bristol (UK): Multilingual Matters. 
Dosia, P. A., \& Rido, A. (2017). Production of English Diphthongs: A Speech Study. Teknostatik Volume 15 (1), 21-35.

Eberhard, D. M., Simons, G. F., \& Fennig, C. D. (2020). Ethnologue: Languages of the World. Twenty-third edition. Dallas, Texas: SIL International.

Enxhi, S. Y., Hoon, T. B., \& Fung, Y. M. (2012). Speech disfluencies and mispronunciations in English oral communication among Malaysian undergraduates. International Journal of Applied Linguistics \& English Literature, 1(7), 19-32.

Farheen. (2020). Languages In Malaysia: Learn More About Malaysia. Retrieved from Pickyourtrail : https://pickyourtrail.com/blog/languages-in-malaysia/

Gilakjani, A. P. (2011). A study on the situation of pronunciation instruction in ESL/EFL classrooms. Journal of Studies in Education, 1(1), 1-15.

Gilakjani, A. P. (2016). English Pronunciation Instruction: A Literature Review. International Journal of Research in English Education Vol. 1, No. 1; 2016.

Gilakjani, A. P., \& Ahmadi, M. R. (2011). Why is Pronunciation So Difficult to Learn? English Language Teaching Vol. 4, No. 3, 74-83.

Gilakjani, A. P., \& Sabouri, N. B. (2016). How can EFL teachers help EFL learners improve their english pronunciation? Journal of Language Teaching and Research (Vol. 7, Issue 5), $967+$.

Gusdian, R. I. (2021). Errors in Long Vowel Pronunciation: A case of English Language Education Department Students. Magister Scientiae, Vol 49 (1), 45-51.

Hagsand, A. V., Roos af Hjelmsater, E., Granhag, P. A., \& Fahlke, C. (2017). Witnesses stumbling down memory lane: The effects of alcohol intoxication, retention interval, and repeated interviewing. Memory, 25(4), 531-534.

Hashim, A. (2020). Malaysian English. In K. Bolton, W. Botha, \& A. Kirkpatrick, The Handbook of Asian Englishes, First Edition (pp. 373-397). John Wiley \& Sons, Inc.

Henry, L., Messer, D., Wilcock, R., Nash, G., M, K.-S., Hobson, Z., \& Crane, L. (2017). Do measures of memory, language, and attention predict eyewitness memory in children with and without autism? Autism \& Developmental Language Impairments,, 2(1), 4468.

$\mathrm{Hu}$, R. (2016). The Age Factor in Second Language Learning. Theory and Practice in Language Studies, Vol. 6, No. 11, 2164-2168.

Ikhsan, M. K. (2017). Factors Influencing Students' Pronunciation Mastery at English Department of STKIP PGRI West Sumatera . Al-Ta'lim Journal, 24 (2), 110-117.

Islam, S. M. (2020). Segmental Errors in English Pronunciation of Non-Native English Speakers. Journal of Education and Social Sciences, Vol. 16, Issue 1, 14-24.

Ismael, R. R. (2021). The Impact of Assimilation and Some Phonetic Patterns on English Language Pronunciation. Iraq: Salahaddin University-Erbil.

Iwai, Y. (2011). The Effects of Metacognitive Reading Strategies: Pedagogical Implications for EFL/ESL Teachers [J]. The Reading Matrix, 150-159.

Jack, F., Leov, J., \& Zajac, R. (2014). Age-related differences in the free-recall accounts of child, adolescent, and adult witnesses. Applied Cognitive Psychology, 28(1), 30-38.

Jamaluddin, K. (2007). Teaching of Science and Mathematics - Phase in English at Secondary Level. . Retrieved from The Malaysian Bar: http://

www.malaysianbar.org.my/index2.php?option=com_content\&do_pdf=1\&id=12619.

Jarosz, A. (2019). English Pronunciation in L2 Instruction: The Case of Secondary School Learners. Switzerland: Springer. 
Jassem, Z. A. (2014). English and Malaysian English Vowels: Theoretical and Applied Perspectives. Journal of ELT and Poetry; A Peer reviewed International Research Journal Vol.2. Issue.1, 5-11.

Jaya, A. R. (2009). The Students Mastery in Pronuncing English Plosive Consonant [ $p, t, k, b, d$, g] . Semarang State University.

Jones, A. M., Bergold, A. N., Dillon, M. K., \& Penrod, S. D. (2017). Comparing the effectiveness of Henderson instructionsand expert testimony: Which safeguard improves jurors'evaluations of eyewitness evidence? Journal of Experimental Criminology, 13(1), 29-52. doi:10.1007/s11292-016-9279-6

Josh. (2019). Manners of articulation. Retrieved from Linguistics Study Guide: https://linguisticsstudyguide.com/manners-of-articulation/

Kachru, B. B. (1986). The Alchemy of English. US: Pergamon Press.

Kachru, B. B. (2006). English: World Englishes. In K. Brown, Encyclopedia of Language \& Linguistics. Elsevier Ltd.

Kachru, Y., \& Smith, L. E. (2008). Cultures, contexts and world Englishes. London: Rouledge.

Kho, I. C. (2011). An Analysis of Pronounciation Errors in English of Six UTAR Chinese Studies Undergraduates. Universiti Tunku Abdul Rahman.

Kim, L. S., \& Hall, S. J. (2019). Manglish : Malaysian English at its Wackiest. Marshall Cavendish International Asia Pte Ltd.

Kirkpatrick, A. (2012). English as an Asian Lingua Franca: the 'Lingua Franca Approach' and implications for language education policy. Journal of English as a Lingua Franca 1(1), 121-139.

Kozhevnikova, E. (2019). The Impact of Language Exposure and Artificial Linguistic Environment on Students' Vocabulary Acquisition. PEOPLE: International Journal of Social Sciences Volume 5 Issue 1, 430-439.

Lathifah, N. N. (2018). English Phonological Assimilation Applied in "English With Lucy" Channel on YouTube. Faculty of Humanities, Universitas Islam Negeri Maulana Malik Ibrahim Malang.

Lee, Z. E. (2015). Colloquial Malaysian English (CMalE): A problem or a cool phenomenon? Repositori Universitat Jaume I.

Lin, D. T., Choo, L. B., Kasuma, S. A., \& Ganapathy, M. (2018). Like That Lah: Malaysian Undergraduates' Attitudes Towards Localised English. Gema Online Journal of Language Studies Vol 18, No 2, 80-92.

Long, C., Chen, L., \& Ming, Z. (2013). The Study of Student Motivation on English Learning in Junior Middle School -- A Case Study of No.5 Middle School in Gejiu. English Language Teaching Vol. 6, No. 9, 136-145.

$\mathrm{Ma}, \mathrm{B}$. (2013). What Is the Role of L1 in L2 Acquisition?. Studies in Literature and Language Vol. 7, No. 2, 31-39.

Majani, K., Khosravi, M., Kianfar, J., \& Naghibi, A. (2021). Breastfeeding of Infants During The First Two Years of Life and Associated Factors based on BAZNEF Model in Sari, Iran. Journal of Mazandaran University of Medical Sciences 30, no. 192, 151-155.

McNally, R. J. (2016). False memories in the laboratory and in life: Commentary on Brewin and Andrews. Applied Cognitive Psychology,, 31(1), 40-41.

McPhee, I., Paterson, H. M., \& Kemp, R. I. (2014). The Power of the Spoken Word: Can SpokenRecall Enhance Eyewitness Evidence? Psychiatry, Psychology and Law, 21(4), 551-566.

McRae, K. (2014). Eyewitness memory for typical and atypical weapons in cognitive context. Journal of Investigative Psychology and Offender Profiling,, 11(2), 179-189. 
Minnis, S. (2019). Speech Disorders . Retrieved from Healthline: https://www.healthline.com/health/speech-disorders

Mizza, D. (2014). The First Language (L1) or Mother Tongue Model Vs. The Second Language (L2) Model of Literacy Instruction. Journal of Education and Human Development Vol. 3, No. 3, 101-109.

Muftah, M., \& Rafik-Galea, S. (2013). Language Learning Motivation among Malaysian PreUniversity Students. English Language Teaching; Vol. 6, No. 3, 92-103.

Muslim, A.-H.-Q. (2009). Sahih Muslim. Beirut: Dar al-Kitab al-'Arabi.

Nahari, G., \& Pazuelo, M. (2015). Telling a convincing story: Richness in detail as a function of gender and information. Journal of applied research in memory and cognition, 4(4), 363367.

Nair, U. G. (2017). Malaysian English: attitudes and awareness in the Malaysian context. . Journal of Modern Languages Vol. 12 No. 1, 19-40.

Neeley, T. (2012). Global Business Speaks English. Retrieved from Harvard Business Review: https://hbr.org/2012/05/global-business-speaks-english

Neuschatz, J., Wetmore, S., \& Gronlund, S. (2015). Memory Gaps and Memory Errors. Emerging Trends in the Social and Behavioral Sciences: An Interdisciplinary, Searchable, and Linkable Resource, 1-13.

Nkoro, E., \& Uko, K. (2016). Autoregressive Distributed Lag (ARDL) cointegration technique: application and interpretation. Journal of Statistical and Econometric Methods, 5(4), 6391.

Nordquist, D. R. (2019). Basic Grammar: What Is a Diphthong? Retrieved from ThoughtCo.: https://www.thoughtco.com/diphthong-phonetics-term-1690456

Nur Syahida, M. Y., \& Zairil, A. Z. (2017). Pronunciation Problems Among KUIS Students. International Islamic University College Selangor.

Obradovic, S. (2017). Whose memory and why: A commentary on power and the construction of memory. Culture \& Psychology, 23(2), 208-216.

Olshtain, E., Shohamy, E., Kernp, J., \& Chatow, R. (2006). Factors Predicting Success in EFL Among Culturally Different Learners. Language Learning 40(1), 23 - 44.

Phng, S. W. (2017). Vowel variations among speakers of Malaysian English. Graduate Theses and Dissertations.

Pillai, S., \& Ong, L. T. (2018). English(es) in Malaysia. Asian Englishes 20 (2), 147-157.

Platt, J., \& Weber, H. (1980). English in Singapore and Malaysia. Kuala Lumpur: Oxford University Press.

Shak, P. C. S. (2016). Pronunciation Problems: A Case Study on English Pronunciation Errors of Low Proficient Students. International Journal of Language Education and Applied Linguistics (IJLEAL) , Vol. 4, 25-35.

Priya, M. S. N. S. D. K. (2020). Teaching Phonetics to Enhance Pronunciation in an ESL Classroom. Journal of Critical Reviews Vol 7, Issue 2, 669-672.

Puspita, S. E. (2017). Interference of Sambas Malay in Pronouncing English Consonant Sounds. Tanjungpura University.

Rahim, H. A., \& Manan, S. A. (2014). English in Malaysia: postcolonial and beyond. Frankfurt: Peter Lang.

Rajadurai, J. (2007). Intelligible Pronunciation:. THE JOURNAL OF ASIA TEFL Vol. 4, No. 1, 1-25. Rao, S. P. (2019). The Role of English as A Global Language. Research Journal Of English (RJOE), Vol-4, Issue-1. 
Rashid, R. A., Basree, S., \& Yunus, K. (2017). Reforms in the policy of English language teaching in Malaysia. Policy Futures in Education 15(1), 100-112.

Read, J. D., \& Connolly, D. A. (2017). The effects of delay on long-term memory for witnessed events. In The Handbook of Eyewitness Psychology, 1(1), 117-156.

Reiterer, S. M. (2018). Exploring Language Aptitude: Views from Psychology, the Language Sciences, and Cognitive Neuroscience Vol 16. Springer.

Renaldi, A., Stefani, R. P., \& Gulö, I. (2016). Phonological Difficulties Faced by Students in Learning English. The Fourth International Seminar on English Language and Teaching 4, Volume 1, 97-100.

Ritcher, K. (2019). English-Medium Instruction and Pronunciation: Exposure and Skills Development. Poland: Multilingual Matters.

Rosyid, A. (2017). Factors Affecting Efl Learners in Learning English Pronunciation. Pedagogia Vol 8 (2), 436-443.

Sauerland, M., Raymaekers, L., Otgaar, H., \& Memon, A. (2016). Stress, stress-induced cortisol responses, and eyewitness identification performance. Behavioral sciences \& the law, 34(4), 580-594.

Compo, S. N., Carol, R. N., Evans, J. R., \& Pimentel, P. (2017). Witness memory and alcohol: The effects of state-dependent recall. Law and Human Behavior, 41(2), 202.

Setyaningsih, K. P., Wijayonto, A., \& Suparno. (2019). English Vowels and Diphthongs Problems of Sundanese Learners. ELS Journal on Interdisciplinary Studies on Humanities Volume 2 Issue 4, 2019, 571-581.

Shively, R. L. (2008). L2 acquisition of [ $\beta$ ], [ð], and [ ] in Spanish: Impact of experience, linguistic environment, and learner variables. Southwest Journal of Linguistics Vol. 27, No. 2, 79114.

Silva, G., \& Patricia, L. (2011). Strategies to improve english pronunciation in young learners (B.S. thesis). Pontificia Universidad Católica del Ecuador Sede Ambato. Retrieved from http://repositorio.pucesa.edu.ec/handle/123456789/834

Siregar, M., \& Eswarny, R. (2020). Improving Students' Achievement in Speaking Monologue Text by Using Video . Budapest International Research and Critics Institute-Journal (BIRCI-Journal) Volume 3, No 2,, 1343-1351.

Soraci, S. A., Carlin, M. T., Read, J. D., \& Pogoda, T. K. (2017). Psychological impairment, eyewitness testimony and false memories: Individual differences. M Toglia, JD Read, DF Ross and RCL Lindsay, The Handbook of Eyewitness Psychology, 1(1), 23-32.

Steblay, N. K., Wells, G. L., \& Douglass, A. B. (2014). Steblay, N. K., Wells, G. L., \& Douglass, A. B. (2014). The eyewitness post identification feedback effect 15 years later: Theoretical and policy implications. Psychology, Public Policy, and Law, 20(1), 1.

Sudijono, A. (2008). Pengantar Statistik Pendidikan. Jakarta: RajaGrafindo Persada.

Suliman, A. (2014). The Interference of Mother Tongue/Native Language in One's English Language Speech Production. International Journal of English and Education Volume 3(Issue 3), 356 - 366.

Tasnim, Z. (2018). Transformation of English Language in Amitav Ghosh's The Hungry Tide. Advances in Language and Literary Studies Volume: 9 Issue: 3, 145-150.

Utami, A. L. (2018). The Analysis of Junior High School Students' Pronunciation Difficulties in Pronouncing English Consonant Sounds in Private Course in Jambi City. Jambi: Jambi University. 
Warden, R., Armbrust, S. M., \& Linzer, J. (2001). How Mistaken and Perjured Eyewitness Identification Testimony Put 46 Innocent Americans on Death Row. Michigan: Andrews University.

Weijen, D. D. (2012). The Language of (Future) Scientific Communication. Retrieved from Research Trends: https://www.researchtrends.com/issue-31-november-2012/thelanguage-of-future-scientific-communication/

Wells, G. L. (2014). Eyewitness Identification: Probative Value, Criterion Shifts, and Policy Regarding the Sequential Lineup. Current Drections in Psychological Science, 23(1), 1116.

Wells, G., \& Quigley-McBride, A. (2016). Applying eyewitness identification research to the legal system: A glance at where we have been and where we could go. Journal of Applied Research in Memory and Recogition, 5(3), 290-294.

Wixted, J. T., \& Wells, G. L. (2017). Wixted, J. T., \& Wells, G. L. (2017). The relationship between eyewitness confidence and identification accuracy: A new synthesis. Psychological Science in the Public Interest, 18(1), 10-65.

Yadav, M. K. (2014). Role of Mother Tongue in Second Language Learning. International Journal of Research, 572-582.

Yamaguchi, T. (2014). The pronunciation of TH in word-initial position in Malaysian English. English Today, Volume 30, Issue 03, 13-21.

Yoshida, M. T. (2016). Beyond Repeat After Me: Teaching Pronunciation to English. TESOL International Association.

Zoss, J. M. (2015). Adult English Learners' Perceptions of Their Pronunciation and Linguistic Self-Confidence. School of Education Student Capstone Theses and Dissertations, 259.

Zuhaili, M. (2007). al-Mu'tamad fi Fiqh al-Syafi'e. Damsyiq: Dar al-Qalam. Damsyiq: Dar alQalam. 